\title{
Role of the carboxy terminal region of $\beta$ tubulin on microtubule dynamics through its interaction with the GTP phosphate binding region
}

\author{
Rodolfo Padilla ${ }^{a}$, Carlos López Otin ${ }^{b}$, Luis Serrano ${ }^{c}$ and Jesús Avila ${ }^{a}$ \\ ${ }^{a}$ Centro de Biología Molecular (CSIC-UAM). Universidad Autónoma. Canto Blanco. 28049 Madrid. Spain. ${ }^{\mathrm{b}}$ Departamento de \\ Biología Funcional, Facultad de Medicina, Universidad de Oviedo, Spain and ${ }^{\circ} E M B L$, Meyerhofstr. 1, Heidelberg 6900, Germany
}

Received 4 May 1993

The dynamic instability of microtubules depends on the GTP binding to tubulin, the rate of hydrolysis of GTP bound to tubulin molecules, at the microtubule caps, and on the affinity and exchange rate of tubulin for GTP versus GDP. It has been demonstrated that the binding of microtubule-associated proteins (MAPs) such as Tau or MAP2 notably enhances microtubule stability in vivo. These MAPs bind to the tubulin carboxy terminal domain. Consequently, an attractive hypothesis to explain the modulation of microtubule dynamics by MAPs is that the carboxy terminal domain of tubulin interacts with a region close to the GTP binding site, preventing the binding of GTP or exchange of GDP for GTP. By carrying out a combined analysis of crosslınking and limited proteolysis, an intramolecular interaction between the carboxy terminus and the tubulin region containing the GTP binding site in $\beta$ tubulın has been observed. It is proposed that this interaction modifies the binding of GTP to the tubulin $\beta$-subunit and, therefore, affects tubulin assembly dynamics. This suggests a molecular explanation for the effect of MAPs in facilitating tubulın polymerization through the regulation of the interaction of GTP

Tubulın; Protein dynamics: GTP binding

\section{INTRODUCTION}

The discovery of the dynamic instability of microtubules has been one of the most significant advances in the analysis of the function and propertics of microtubules in cells [1]. Dynamic instability is the result of the kinetics of binding and hydrolysis of the GTP molecule bound to the $\beta$-subunit of tubulin [1]. Tubulin containing GTP bound to its $\beta$-subunit in an exchangeable form [2] is incorporated into microtubules. Following the incorporation of tubulin into microtubules, GTP is hydrolyzed to GDP and the resulting microtubules (containing GDP bound to tubulin) are unstable polymers which depolymerize [1]. Various $\beta$-tubulin isoforms have been described and it has been suggested that the dynamic properties of a microtubule are related to its $\beta$-tubulin isotype composition [3]. The various $\beta$-isoforms mainly differ in the sequence of the last 50 amino acids (C-terminal region) $[4,5]$. This $\mathrm{C}$-terminal region is involved in the regulation of tubulin polymerization [6,7], microtubule morphology [8] and in the interaction with the microtubulc-associatcd protcins (MAPs) [8-10]. In the presence of MAPs, microtubule dynamic instability is prevented by an increase in the stability of the polymer [11,12]. In addition, there is an enhancement in the affinity of GTP for the $\beta$-subunit [13] and a reduction of the hydrolysis rate of GTP to

Correspondence address. J Avila, Centro de Biología Molecular, Canto Blanco, 28049 Madrid, Spain.
GDP [14]. The GTP binding region in the $\beta$-subunit has been localized [15] and a possible interaction of the $\mathrm{C}$-terminal region of $\beta$-tubulin with another region located close to that of the phosphate binding site of GTP has becn proposed in a theoretical work [16]. Thus, it is possible that the C-terminal region of the $\beta$-subunit of tubulin participates in the regulation of the dynamic instability of microtubules. In this report we have tested this hypothesis by using a zero-length crosslinker agent (EDC), which joins carboxylates to primary amines, previously used for the $\alpha$-subunit of tubulin [17].

\section{MATERIALS AND METHODS}

\subsection{Protein preparation}

Microtubule protein from bovine brain was prepared by temperature-dependent cycles of assembly-disassembly according to Shelanski et al. [18]. Tubulın was further purified by chromatography on a phosphocellulose column, as described by Weingarten et al. [19]. Subtılısın-digested tubulin (S-tubulın) was isolated as previously described [6].

Tubulin peptides, comprising the residues $133-142$ and $435-449$ from the $\beta$-subunit (type III isoform [20]) were synthesized on an automatic solid phase peptıde synthesizer (type $430 \mathrm{~A}$. Applied Biosystems, Foster City, Ca) and purified by reverse-phase HPLC on a Novapak $C_{18}$ column, using a Waters 501 apparatus. The peptides were subsequently lyophilized.

\subsection{Crosslinking analysis}

The conditions described by Blank et al. [17] were followed. Briefly, tubulin $(1 \mathrm{mg} / \mathrm{ml})$ was mixed with freshly prepared 1-ethyl-3-(3-dimethylamınopropyl)-carbodiimıde (EDC) at a final concentration of $2 \mathrm{mM}$ EDC. The reaction was carried out at room temperature for various times $(1-10 \mathrm{~min})$ and stopped by the addition of glycine at a 
final concentration of $1 \mathrm{M}$, or by the addition of electrophoress sample buffer [23]. For experiments involving enzymatic cleavage of the proten (see below), the crosslinked or uncrosslinked protein was incubated in $6 \mathrm{M}$ urea before protease treatment.

In some cases, after crosslinkıng, the protein was subjected to gel electrophoresis [21] and the protein was stained with Coomassie blue. or characterized by autoradiography in the case of phosphorylated protein.

\subsection{Chemical clearage}

Formic acld at a concentration of $80 \%(\mathrm{v} / \mathrm{v})$ was used to cleave tubulin at the Asp-Pro bonds as previously described [6]. After chemical cleavage, the residue present at the amıno terminus was identıfied as described [22]

\subsection{Protein cleavage}

Chymotryptic digestion [8] of uncrosslinked or crosslinked tubulin was performed by mixing the protease with the substrate (at a ratio 1:20, w/w) in buffer A $\left(0.1 \mathrm{M}\right.$ MES, $2 \mathrm{mM}$ EGTA, $1 \mathrm{mM} \mathrm{Mg}^{2+}, \mathrm{pH}$ 6.4) and incubating for $5 \mathrm{~h}$ at $37^{\circ} \mathrm{C}$. The resulting peptides, dissolved in $0.1 \%$ TFA, were applied to a reverse-phase HPLC column (Novapack $\mathrm{C}_{18}$, Waters Millipore Corp., Bedford, MA) and fractionated using a $0-70 \%$ acetonitrile gradient with a flow rate of $1 \mathrm{ml} / \mathrm{mun}$. Fractions of $0.5 \mathrm{ml}$ were collected and dotted onto nitrocellulose paper to test the reaction of the fractionated peptides with antibodies raised against peptide FQLTHSLGGG (containıng part of the phosphate binding site on $\beta$-tubulin subunt [15] or against peptıde EMYEDDEESESQGPK, corresponding to the carboxy termınus of $\beta$-tubulın (class III) [20]

\subsection{Tubulin phosphorylation}

$\beta$-Tubulın (class III) was phosphorylated at serine-444, by casen kinase II, as previously described [23]

\section{RESULTS AND DISCUSSION}

Tubulin $(1 \mathrm{mg} / \mathrm{ml})$, purified as indicated in section 2 , labeled at its $C$ terminus by phosphorylation in vitro with casein kinase II $[23,24]$ and depleted of microtubule-associated proteins, was tested for its ability to polymerize in the presence of $10 \mu \mathrm{m}$ taxol. More than $90 \%$ of the protein was present in the polymerized fraction, as determined by centrifugation and characterization of the pelleted and non-pelleted protein by gel electrophoresis.

Labeled tubulin was first incubated with the crosslinker EDC and then with formic acid [22], which cleaves between residues aspartic-304 and proline-305 [6]. In the absence of crosslinker, the two fragments can be fractionated by SDS gel electrophoresis. However when tubulin was previously incubated with EDC no fragments were found (Fig. 1), although the protein was indeed cleaved as found by $\mathrm{N}$-terminal sequence analysis of the crosslinked protein (the amino-terminal Met is blocked, and in this case a $\mathrm{N}$-terminal Pro residue was found). The effect of EDC is concentration- and timedependent. Using the right conditions, $100 \%$ of the protein is crosslinked, as found by formic acid digestion (Fig. 1b). These results are consistent with an intramolecular crosslinking of the amino region (residues 1 to 304) and the carboxy region (residues 305 to the end) of $\beta$ tubulin by EDC. On the other hand, when subtili- sin-digested tubulin, deprived of part of the $C$-terminal region [6], was subjected to the same experiment, only a small percentage of the $\beta$-subunit was found to be

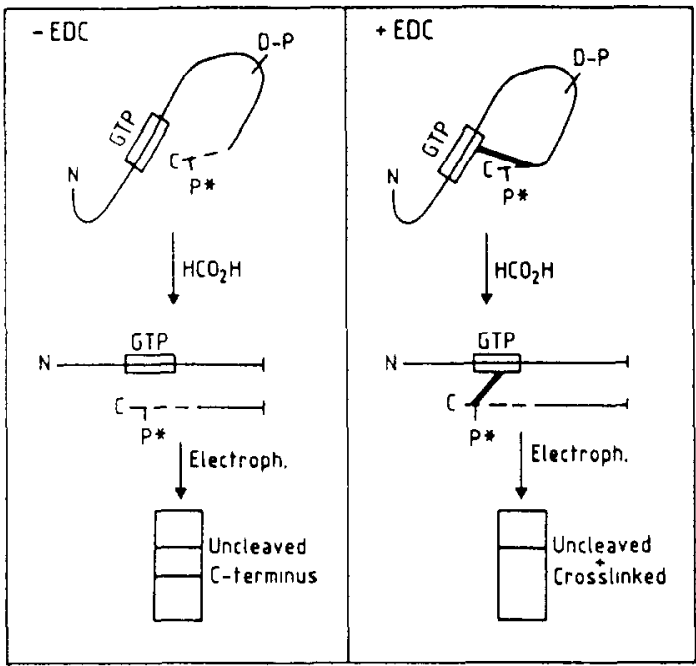

b

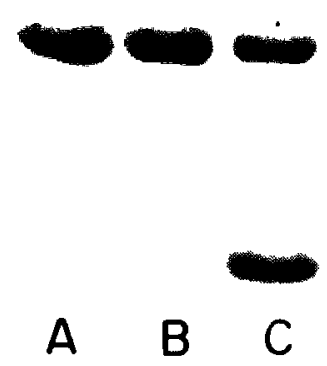

Fig. 1. Crosslinking of $\beta$ tubulin identified after proteolytic cleavage (a) Scheme of analysis: $\beta$-tubulin subunit (labeled at its $C$-terminus), after treatment (right) or without treatment (left) with FDC is digested with formic acid. The digested products are fractionated by electrophoresis and characterized by autoradiography as indicated in the scheme. (b) Experimental; Microtubule protein from bovine brain was prepared by temperature-dependent cycles of assembly-disassembly accordıng to Shelanskı et al. [18]. Tubulın was further purıfied by chromatography on a phosphocellulose column, as described by Weingarten et al. [19] and the $\beta$-subunit (class III) was phosphorylated at scrinc-444 with $\mathrm{AT}^{32} \mathrm{P}$, by casein kinase $\mathrm{II}$, as previously indicated [23]. The labeled tubulın was then mixed, at a concentration of 1 $\mathrm{mg} / \mathrm{ml}$, with freshly prepared 1-ethyl-3 (3-dimethylamino propyl) carbodumide (EDC), at a final concentration of $2 \mathrm{mM}$ EDC. The reaction was carried out at room temperature for various times (1-10 min) and stopped by the addition of glycine at a final concentration of $1 \mathrm{M}$. The crosslinked or uncrosslinked protein was incubated with formıc acid at a concentration of $80 \%(\mathrm{v} / \mathrm{v})$ as previously described [6]. (A) Uncleaved protein. (B) Chemical cleavage of EDC crosslinked tubulin labeled at the $\mathrm{C}$ termınus of $\beta$-subunit. $(C)$ Chemical cleavage of uncrosslinked tubulın labeled at the $C$ terminus of $\beta$-subunit. There are two peptides corresponding to the uncleaved subunit and to the 

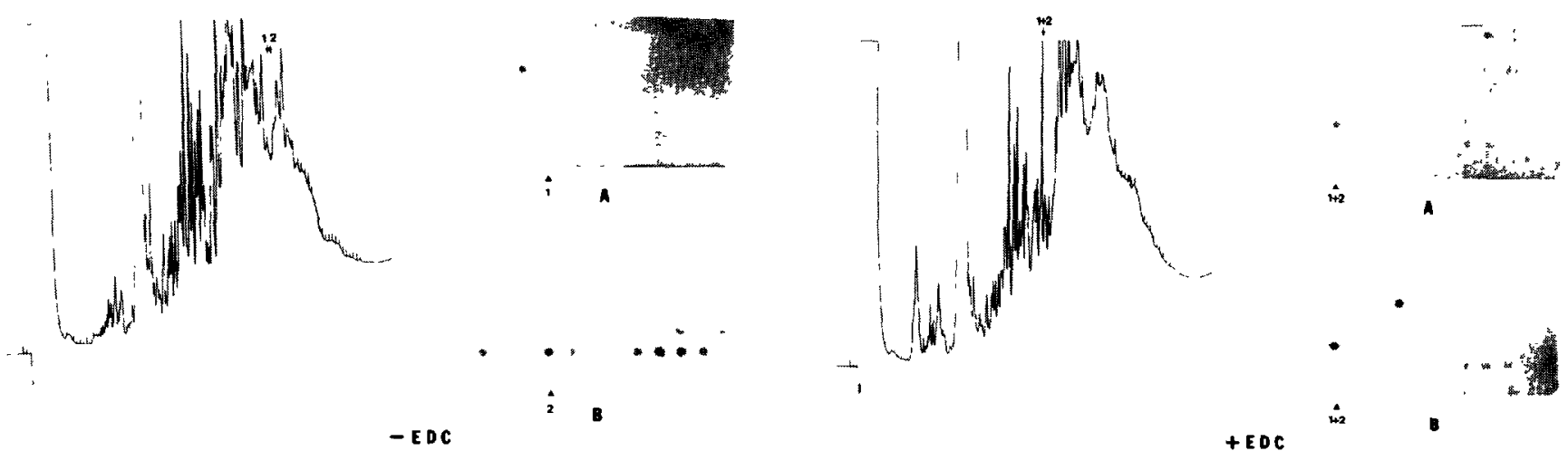

Fig. 2. Identification of the crosslınked peptide fragments by proteolytic cleavage Tubulin crosslinked, or uncrosslinked, in the same way as indicated in Fig. 1, was exhaustively digested with chymotrypsin by mixing the protease with the substrate (at a ratio $1: 20$, w/w) in buffer $\mathrm{A}(0.1$ M MES, $2 \mathrm{mM}$ EGTA, $1 \mathrm{mM} \mathrm{Mg}^{2+}, \mathrm{pH} 6.4$ ), and incubating for $5 \mathrm{~h}$ at $37^{\circ} \mathrm{C}$. The resulting peptides were applied to a reverse-phase $\mathrm{HPLC}$ column (NOVA PAK C-18, Waters Millipore Corp., Bedford, MA) and fractionated using a 0-70\% acetonitrile gradient in 50 min with a flow rate of 1 $\mathrm{ml} / \mathrm{m} \mathrm{n}$. Fractions of $0.5 \mathrm{ml}$ were collected and dotted onto nitrocellulose paper to test the reaction of the fractionated peptides with antibodies (A) raised against peptide FQLTHSLGGG (containing part of the GTP phosphate binding site on $\beta$-tubulın subunıt [5]), or (B) against peptıde EMYEDDEESESQGPK, corresponding to the $C$ terminus of $\beta$ tubulin (class III).

crosslinked (less than $3 \%$ ), suggesting that the deleted region is involved in the crosslinking (data not shown). To further characterize the regions involved in the crosslinking reaction, monomeric tubulin crosslinked, or not, with EDC was exhaustively digested with chymotrypsin and the fragments were fractionated by HPLC. An antibody against the carboxy terminus of $\beta$-isoform III (EMYEDDEESESQGPK), was used to screen for the presence of the C-terminal region of this isoform in the various fractions. An antibody against the sequence FQLTHSLGGG (residues 132-142) of $\beta$ tubulin was used to screen for the presence of the GTP phosphate binding region [15]. It was found that in the presence of EDC three new peaks, with a molecular weight of less than $8 \mathrm{kDa}$ (data not shown). containing both regions were present (Fig. 2). $\mathrm{N}$-terminal sequence analysis of one of the fractions containing the C-terminal region of $\beta$-isoform III, without treatment with EDC, resulted in the sequence $\mathrm{Q} / \mathrm{Q} / \mathrm{X} / \mathrm{Q}$ that may correspond to residues 423 to 426 of $\beta$ tubulin. This sequence is preceded by Tyr-422, a specific residue for chymotrypsin cleavage and may correspond to a $\sim 3 \mathrm{kDa} C$ terminal fragment. In the case of $\beta$ tubulin previously treated with EDC the sequence analysis of one of the new peaks resulted in a mixture of at least two sequences: Q/Q-E/X-G/Q-X/D-E. Part of the sequence corresponded to the $\mathrm{C}$-terminal fragment previously

C-terminal fragment (residues 305 to the end). There is only one peptide corresponding to the size of the undigested tubulin. The $\mathrm{N}$ terminal amino acid of this crosslinked cleaved tubulin was determined by using an Applied Biosystems gas-phase sequenator (model $470 \mathrm{~A}$ ) equipped with an on-line phenylthiohydantoin amino acid analyzer (model $120 \mathrm{~A}$ ). and it was found to be Pro, indicating that it was cleaved and that the C-terminal fragment is crosslinked to the $\mathrm{N}$ terminal fragment. analysed $(\mathrm{Q} / \mathrm{Q} / \mathrm{X} / \mathrm{Q})$, while the rest $(\mathrm{E} / \mathrm{G} / \mathrm{X} / \mathrm{E})$ may correspond to a peptide starting at residue 108 of $\beta$-subunit III (E/G/A/E/L). This sequence is preceded by Thr-107 (an amino acid found that could be a substrate for chymotrypsin [25]) and could be finished at Phe-132, containing a Lys (residue 122) that could be crosslinked to any of the Glu residues of the C-terminal fragment. This would result in a 3 to $4 \mathrm{kDa}$ fragment that together with the $3 \mathrm{kDa}$ fragment of the C-terminal region of $\beta$-isoform III will give $\mathrm{a} \sim 7 \mathrm{kDa}$ fragment, as found on SDS gels (data not shown).

Additionally, the sequence analysis of another HPLC peak reacting with both $\beta$-tubulin antibodies revealed the partial amino terminal sequence (V-Q/R-Q). Part of the sequence. $V / R$, may correspond to residues 120 and 121, close to the GTP binding site, and another part, $\mathrm{Q} / \mathrm{Q}$, may correspond to residues 423 and 424 present at the C-terminal region.

It has been indicated that the carboxy terminal region of the tubulin subunit is relatively mobile and that this mobility could result in various protein conformations [26]. In the absence of MAPs, the carboxy terminus region may interact with a region very close to the proposed GTP phosphate binding site and interfere either with GTP binding, with GTP hydrolysis or with the exchange of GDP for GTP. In the presence of MAPs of the Tau/MAP2 family [27-31], which bind to the C. terminal region of tubulin [6], the previous conformation is not possible and the interference disappears, thus facilitating tubulin assembly. This is consistent with the facilitation of nucleotide binding to tubulin by MAPs [13] and with the fact that the assembly of tubulin lacking its C-terminal region cannot be promoted by MAPs or polycations, and is inhibited by polyanions like polyglutamic acid that resemble the $\mathrm{C}$-terminal region of $\beta$ tubulin [32].

On the other hand, the interference with GTP hydrol- 
Table I

Comparison of the $\beta$-tubulin region containing the GTP phosphate binding site and those of MAP2 and Tau containıng tubulin-binding motifs

$\beta$-tubulın MAP2 (Repeat 1)

Tau (Repeat 1)

\section{STCDCLQGFQLTIISLGGG}

TSKCGSLKNIRHRPGGG QSKIGSLDNITHVPGGG

The sequence for the GTP phosphate binding site in mammalian $\beta$-tubulin subunit [15] is shown together with those of the first tubulin binding motif of MAP2 [27], and Tau [26]. The presence of 1dentical residues (bold) or conservative changes (underlined) is indicated

ysis seems unlikely, since nucleotide hydrolysis appears to decrease microtubule stability [33]. Additionally, a possible interference of the $\beta$ tubulin C-terminus with the exchange of GTP for GDP could be discussed if it is assumed that nucleotide exchange only occurs on the disassembled dimer and not in assembled tubulin. In this way, the absence of GTP exchange in the polymer may be explained if it is postulated that a tubulin-tubulin binding site lies close to the exchangeable GTP binding site, causing the nucleotide to be trapped in the polymer. In this case, tubulin-tubulin interaction could be blocked if the $\mathrm{C}$-terminus occupies the phosphate binding site. As a possible consequence of this, the effect of GTP in promoting microtubule assembly might be to displace the $\mathrm{C}$ terminus from the proposed binding site.

Also, by looking at the GTP phosphate binding region of $\beta$ tubulin and comparing its sequence to the common tubulin binding domain of the Tau/MAP2 family $[27,28]$, a similarity was observed in the primary sequence (see Table I). Thus, it could be suggested that the C-terminus of $\beta$ tubulin interferes with the GTP binding site of $\beta$ tubulin and therefore, different isoforms containing different sequences at their $C$ termini could result in different dynamic properties of the microtubules. Also, various MAPs of the Tau/MAP2 or MAP4 family [29-31] having slight differences in the tubulin domain could result in differing degrees of microtubule stabilization.

Acknowledgements. We acknowledge Drs. A Matus and J Díaz-Nido for comments on this work and Ms. Helen Fry for Fnglısh corrections. This work was supported by grants from CICYT (Spain) and from an Institutional Grant of Fundación Ramón Areces.

\section{REFERENCES}

[1] Mitchison. T. and Kirschner, M. (1984) Nature 312, $237-242$.

[2] Carlier, M.F. (1982) Mol. Cell Biochem. 47, 97-113.
[3] Rothwell, S.W., Grasser, W.A. and Murphy, D.B. (1986) Ann. NY Acad. Sci. 466, 103-110

[4] Wang, D.A., Villasante, A, Lewis, S A. and Cowan, N.J. (1986) J. Cell Biol. 103, 1905-1910.

[5] Sullivan, K. and Cleveland, D.W. (1986) Proc. Natl. Acad. Sci. USA $183,4327-4331$.

[6] Serrano, L.. de la Torre, J.. Maccionı. R.B. and Avıla. J (1984) Proc. Natl. Acad Sc1. USA 81, 5989-5999.

[7] Sackett, D., Bhattacharyya, B. and Wolff, J. (1985) I. Biol. Chem 260. $43-46$

[8] Serrano, L.. Wandosell, F., de la Torre, J and Avila, J. (1986) Methods Enzymol. 134, 179-190.

[9] Littauer, U.Z, Giveon. D.. Thierauf, G., Ginsburg. I. and Ponstingl, H. (1986) Proc. Natl. Acad Sc1 USA 83, 7162-7166.

[10] Cross, D.. Dominguez, J., Maccioni, R. and Avıla, J (1991) Biochemistry $30,4362-4366$.

[11] Hotani, H. and Horio, T. (1988) Cell Motıl. Cytoskel. 10, 229 236.

[12] Drubin, D.G. and Kirschner, M.W. (1986) J. Cell Biol. 103, 2739-2746.

[13] Hamel, E . del Campo. A., Lutsbader, J. and Lin. C M. (1983) Biochemistry 22, 1271-1279.

[14] Mejillano, M . Tolo, E., Willıams, Jr. R. and Himes, R.H. (1992) Biochemistry 31, 3478-3483.

[15] Linse. K. and Mandelkow, E.M. (1988) J. B1ol. Chem. 263, 15205-15210.

[16] Burns, R.G. and Surridge, C. (1990) FEBS Lett. 271, 1-4.

[17] Blank. G.S., Yaffe. M.B., Szasz, J., George, E., Rosenberg, T.L and Sternlıcht, H (1986) Ann. NY Acad. Sc1 466, 467-481.

[18] Shelanski, M.L.. Gaskın, F. and Cantor, C.R. (1973) Proc. Natl Acad. Sci. USA 70. 765-768.

[19] Werngarten. M.D., Lockwood, A.H., Hwo, S. and Kurschner, M.W. (1975) Proc. Natl. Acad. Sci. USA 72, 1858-1862.

[20] Cleveland, D.W. (1987) J. Cell Biol 104, 381-383.

[21] Laemmli, U.K. (1970) Nature 227, 680-685.

[22] Jauregui-Adell, J. and Marti, J. (1975) Ann. Bıochem. 69, 468473.

[23] Diaz-Nido, J., Serrano, L., López Otín, C., Vandekerckhove, J. and Avila, J. (1990) J. Biol. Chem. 265, 13949-13954.

[24] Serrano, L.. Díaz-Nido. J., Wandosell, F. and Avila. J. (1987) J Cell Biol. 105. 1731-1739.

[25] Wilkınson, J.M (1986) in: Practıcal Protein Chemistry. A Handbook (A. Darbre. Ed) pp 121-148, Wiley, Chichester.

[26] Ringel, I. and Sternlicht, H (1984) Biochemıstry 23, 5644-5653.

[27] Lee, G., Cowan, N. and Kırschner, M. (1988) Science 239, 285288.

[28] Lewis, S.A., Wang, D. and Cowan. N.J. (1988) Science 242. 936-939.

[29] West, R.B., Tenbarge, K.M. and Olmsted, J.B. (1991) J. B1ol. Chem. 266, 21886-21896.

[30] Chapin, S.J. and Bulınski, J C. (1991) J. Cell Sci. 98, 27-36.

[31] Aizawa, H.. Emorı. Y., Mori, A., Murofushı, H., Sakai. H. and Suzuki. K. (1991) J. B1ol. Chem. 266. 9841-9846.

[32] Serrano, L., Maccioni, R.B. and Avila, J. (1986) Ann. NY Acad. Sci $466,642-644$

[33] Hyman, A.A., Salser, S., Drechsel, D N., Unwin, N. and Mitchison. T.J. (1992) Mol. Biol. Cell 3, 1155-1167. 